\title{
EDITORIAL
}

\section{Clonal origin of leukemia - revisited. A tribute to Philip J Fialkow, MD}

\author{
V Najfeld \\ Tumor Cytogenetics Laboratory, Box 1079, Department of Medicine, Mount Sinal School of Medicine, One Gustave L Levy Place, New \\ York, New York 10029, USA
}

Keywords: CML; clonality; leukemia

This issue of Leukemia is dedicated to Philip J Fialkow, MD, who together with his wife Helen, died in November 1996 while trekking in Nepal. Four of the following papers were presented in part at the American Society of Hematology Annual Meeting in San Diego on 6 December 1997, where the Scientific Subcommittee on Neoplasia of the American Society of Hematology held a symposium entitled 'A Clonal Origin of Leukemia - Revisited. A Tribute to Philip J Fialkow, MD'. Dr Nicole Muller-Berat, the Editor-in-Chief and Founder of Leukemia, graciously extended an invitation for publication of the presentations given in the symposium in memory of her husband and her interactions with Phil Fialkow.

These papers on clonality honor Dr Fialkow's enormous contribution to the current understanding of the origin and development of malignant hematopoietic disorders and discuss current technology as well as the future of clonality studies in neoplasia.

Philip Fialkow was born in New York City in 1934. After graduating from the Bronx High School of Science, he received a BA in Philosophy from the University of Pennsylvania in 1956. He graduated cum laude from Tufts University School of Medicine in 1960 and was married to Helen Dimitrakis on his graduation day. After completing his internship and first residency year at the University of California at San Francisco he came to the University of Washington in Seattle, for his second residency year. Developing an interest in human genetics, he pursued a 2-year fellowship with Arno Motulsky, MD, a pioneer in medical genetics. After completing the fellowship in 1965, he joined the Faculty of Medicine, rising to the rank of full professor in only 8 years.

Philip Fialkow published more than 200 papers, including 70 during the decade he served as Chairman of Medicine at the University of Washington School of Medicine (19801990). In 1988, he received a prestigious National Institutes of Health merit award to continue support for his research on the origin of human tumors. He was elected a member of the Institute of Medicine of the National Academy of Sciences in 1991. In 1995, he received the Mayo Soley Award from the Western Society for Clinical Investigation for his contributions to the study of stem cell origins of leukemia. Shortly before his death, Fialkow was elected as a fellow of the American Association for the Advancement of Science. At that time, he

Correspondence: V Najfeld; Fax: 212 996-1029

A Symposium held on 6 December 1997 at the American Society of Hematology Annual Meeting in San Diego, USA, by the Scientific Subcommittee on Neoplasia. Guest Editor and Organizer of this Symposium Dr Vesna Najfeld.

Received 8 November 1997; accepted 9 November 1997 was the Dean of the School of Medicine and the Vice President for Medical Affairs at the University of Washington.

In 1975, when I was completing my PhD thesis in London, UK, I read the paper by Fialkow, Gartler and Yoshida entitled 'Clonal origin of chronic myelocytic leukemia in man' published in the Proceedings of the National Academy of Science in $1967 .{ }^{1}$ The paper was published only 7 years after the discovery of the Philadelphia ( $\left.\mathrm{Ph}^{\prime}\right)$ chromosome, the first chromosomal abnormality associated with human malignancy. I was impressed by the elegance of the experimental design utilizing G6PD as a marker to trace the origin of human tumors. I applied by letter for a fellowship but apparently 'no funds were available'. A certain dose of luck and serendipity, in addition to hard work, is sometimes helpful in an academic career. A few months later, at a scientific meeting in London, I approached Philip Fialkow during the tea break with a question related to the $\mathrm{Ph}^{\prime}$ chromosome. Only after 15 min of discussion, I introduced myself. Seven days later I was awarded a fellowship in Fialkow's laboratory. This was the beginning of a friendship which lasted 21 years, until the day the tragic news from Katmandu reached me.

In a seminal paper on the clonal origin of chronic myelogenous leukemia $(\mathrm{CML})$, mentioned above, ${ }^{1}$ Fialkow and his colleagues were the first to provide evidence that the leukemic process was clonal, and later demonstrated that CML involved a stem cell. This paper was among the first demonstrating how the phenomenon of cellular mosaicism, resulting from $X$ chromosome inactivation, could be used to analyze the origin of cancer. His research on the origin of hematopoietic disorders was extremely productive and resulted in over 150 papers, review articles, textbook chapters and proceedings from symposia. A review of some of the more important findings to come from these collaborations is provided in the first paper of this issue of Leukemia, entitled 'Clonal development of myeloproliferative disorders: clues to hematopoietic differentiation and multistep pathogenesis of cancer'.

In addition to the studies on human hematopoietic disorders, Fialkow and his collaborators made important contributions in many other areas. An early interest in the relationship between autoimmune disorders and chromosome aberrations was pursued. ${ }^{2,3}$ A mouse model of skin carcinogenesis was created to study multistep development of a solid tumor in an experimental system. ${ }^{4}$ The X-linked enzyme PGK replaced the G6PD model as a marker in these studies. Similarly, he supported development of another experimental model, an interspecific feline hybrid, in which G6PD was the marker used to investigate a virally induced leukemia. ${ }^{5}$ The pathogenesis of a virally associated human malignancy, Burkitt's lymphoma, had also been extensively studied. 6,7 Furthermore, Fialkow wrote many papers on clinical genetics and other medical topics.

Philip and Helen Fialkow were passionate and experienced hikers and were fascinated by other cultures. They combined 
these two passions in repeated trips to Nepal. It was during their fourth journey in the Himalayas, setting out to visit the 800-year-old Tse Gomba Buddhist monastery that they encountered unseasonably cold and stormy conditions just after crossing a pass at an elevation of approximately 17000 feet. Three guides were sent for help but nine feet of snow buried the camp during the night. On November 3, a rescue team confirmed the fears that had grown during the week of waiting for news.

The qualities that enabled Philip Fialkow to establish and maintain a successful worldwide research collaboration were manifested in his equally successful administrative career. As one of his students, colleagues, collaborators and friends I would like to add that Phil's vision, scientific honesty, careful interpretation of scientific data, teaching, and above all, a deep respect and quiet warmth for each and every member of his team made research collaborations truly exciting. I miss him.

\section{References}

1 Fialkow PJ, Garler SM, Yoshida A. A clonal origin of chronic myelocytic leukemia in man. Proc Natl Acad Sci USA 1967; 58: 1468-1471.

2 Fialkow PJ. 'Immunological' oncogenesis. Blood 1967; 30: 388394.

3 Fialkow PJ. Autoimmunity and chromosomal aberrations. Am J Hum Genet 1966; 18: 93-108.

4 Reddy AL, Fialkow PJ. Skin papillomas induced by initiation promotion differ from those induced by a carcinogen alone. Nature 1983; 304: 69-73.

5 Abkowitz JL, Ott RL, Nakamura JM, Steinmann L, Fialkow PJ, Adamson JW. Feline glucose-6-phosphate dehydrogenase cellular mosaicism: application to the study of retrovirus-induced pure red cell aplasia. J Clin Invest 1985; 75: 133-140.

6 Fialkow PJ, Klein G, Gartler SM, Clifford P. Clonal origin for individual Burkitt tumors. Lancet 1970; 1: 384-386.

7 Fialkow PJ, Klein E, Klein G, Clifford P, Singh S. Immunoglobulin and G6PD as markers of cellular origin in Burkitt lymphoma. J Exp Med 1973; 138: 89-102. 